\title{
BUSINESS AS A COMPONENT MECHANISM OF SOCIAL PROTECTION OF POPULATION
}

The social protection of population is a main direction of activities of any government. In modern period social protection of population is proceeding with the help of social policy. Mainly social policy implementation is done by the government. Currently in Georgia the main mechanism for social protection is social insurance, which is carried out by the Ministry of Labor, Health and Social Affairs. In Georgia social subsidy agency is responsible for the health insurance and medical programs. Under condition of marketing economy the limitation of interference of government in economy decreased means of social protection. In the modern conditions social protection mechanism should be developed jointly by the government and private sector measures. It becomes necessary to increase the role of business in the social protection of population, which with the difference of charity requests more social responsibility. The most important goal of any government is the effective employment of its population. The research objective is to explore the role of business in the social protection; to set the problems and find the concrete proposals for solving these problems. It is clear that operation of social policy measures can be entirely imposed on the business. As well as the business can ensure effective functioning of the employment level and thus contribute to the development of their own businesses as well as the social policy of government.

This paper formulates proposals is direction of the interaction of business and government, their activities for effective social protection of population.

Key words: social insurance, social policy, social protection

Asie Tsintsadze, Full time Professor, Faculty of Economics and Business, Batumi Shota Rustaveli State University, Georgia, e-mail: asinsaze@rambler.ru

* Lilit Meloyan-Phutkaradze, Assistant Professor at the Faculty of Economics and Business, Batumi Shota Rustaveli State University, Georgia, e-mail: lilmeloyan@yahoo.com 


\section{Introduction}

The important issue of business development in modern period is the social responsibility of business. The achieved success in all spheres of public life of developed countries showed that, despite the evaluation by theoretical aspects of market economy, it is considered as basis of social class differentiation of society, that the market economy divides people by "rich" and "poor". The market economy by its nature is "the social" and therein lies all mechanism, the proper use of which serves the interests and needs of people.

The current situation in the world practice have undergone all countries and there is strong sense that it is impossible to develop the national economy, to gain competitiveness in the world market, to increase investment attractiveness, if all politics is not directed to improve the social situation of human capital.

\section{Chapter 1. visions of business in social responsibility}

\subsection{European Models of Business Social Responsibility}

The governments of UK and EU discuss the social responsibility of the business as one aspect of good corporate management, their voluntary activities. But in some cases, is the requirement for business to reallocate resources in terms of social, in the form of compulsory system of the value. But the development of business, its successful activity depends largely on in the existence of socially ensured society, so social responsibility will be or not the voluntary action, the business is obliged to answer the echo from the society.

If we will analyze all factors of business activity: entrepreneurial skill, capital, the land, the labor tools and labor force - it is easy to guess that, all factors will be motionless without the labor force. The formula for business success is the connection of producing factors with the person, which appears in this formula as not only the labor force, also produced goods and user of services. According to this logic, the social politics should not be the burden of business, in the social policy implemented by the state the business should be socially responsible for employed people.

According to the European commission, the social responsibility is the concept, and with the help of it, the company makes the integration of social responsibility and environmental protection liabilities of its activities and in the relationship with the partners" (Communication, 2011) (COM, 2001, p. 366) 


\subsection{American model of business social responsibility}

"According to view of the Nobel Prize Laureate in the field of Economics Milton Friedman: the businesses have only one responsibility - to use its resources in order to bring the profits, as long as these activities fit into the rules of the game." (Friedman, 2006, p. 111). So according to the Friedman's view, the role of the company is to earn the money and not in saving parliament or other humanism. Corporative American model of the social responsibility established in $19^{\text {th }}$ century. Due to the peculiarities of American entrepreneurship, which based on maximum freedom of subject, many field of society relations stay as self-regulated. Among them the labor relations - employee and employer (bilateral agreement), and voluntariness of medical insurance. But business participation mechanism is sophisticated (trough corporative funds) in social support. To solve different social problems by business expense (sponsoring of pension provision for staff, insurance programs and professional education). If the American model the designation of corporative social responsibility discusses the responsibility to shareholders and profitability, the European model places responsibility on it in connection with the worker's and local society unions. The charity projects is not so popular in Europe as in USA, which explained by more substantial tax burden.

\subsection{Theories of business social responsibility}

Formulated two opposite theory about social responsibility of business: according to corporative altruism, the companies are obliged to improve the quality of citizens life (use in Japan), and on the others hand the theory of corporative selfishness (Friedman, 1970, p. 32-33; p. 122-126) argues that, the business is obliged for increasing the incomes of shareholders, there are many intermediate approach between these two different positions. One of them is "the theory of discreet selfishness", according to this theory the company reduces the current profit by the social expenses and charity, and creates favorable social environment to get high profit in future. Among the followers of these two theories still is being acute polemics. The followers of "corporative selfishness theory" are calling this theory "destructive" which is built on lies, because is based on "suspicious and erroneous assumptions", which leads to the growth of the company's expenses and the deterioration of activity results. The followers of less radical approaches were trying to find the place of social corporative responsibility in the theory of Friedman. For example, Douglas Denull argued that, the concept of Friedman detects principles of corporative social responsibility, but in somewhat limits the interests of shareholders, in order to improve it, he offers the rulers of corporation to sign the special agreement for maximization of profits with shareholders. The discussion about social responsibility of business against the 
background of this theory might be a little early to be considered in the reality of Georgia, but if we recall the business history of the past century of Georgia, the institute of Georgian charity and philanthropy has quite serious tradition. In spite of this, the social and altruistic projects confined to simple sponsorship, often by promotional campaigns, there is quite "discreet egoism", but these campaigns mainly have non-systematic and non strategic nature. As for the funds and special altruistic NGOs initiated by the business, in this respect none of them is not distinguished particularly active. It is considered, that the social responsibility of business needs strengthening and increasing.

\subsection{Business social responsibility in Georgia}

According to the poll of Georgian strategic research and development center, $29 \%$ of businessmen could not explain the social responsibility, and the others the social responsibility discuss as the responsibility against the employees, payment of taxes, business transparency. Only a small part of businessmen are thinking, that the social responsibility implies funding of social sphere, care for society, to solve the problem of unemployment. Despite the fact, that the large part of Georgian companies the social responsibility understand narrowly and straightforward, a small part of them are still trying to input the social responsibility components in their activities. For example, "Wissol group" has the position of social responsibility manager. The social responsibility for them is the care for "market and customers, employees, health care, environment protection and business-partners", but in practice focused on transport, construction of churches and takes care of socially vulnerable children.

There is a great difference between the social responsibility of business of western companies and the social responsibility of business in Georgia, because the social responsibility in Georgia is considered as single action, and the western companies are implementing long-term social projects. Single charity cannot create feeling in the society, which once received social aid in case of need reoccurs.

The social responsibility of any organization has an important advantage for potential buyer. If the charity projects allows to customers to share emotional mood, the social responsibility - is the effective strategy of company working for mass market, which promotes the realization of corporative values and the extraction of customer's loyalty. In order to study the social responsibility were surveyed 42 companies in Georgia. The poll was held with the groups of individual interests, from the received answer determined, that $65 \%$ of employed people are not socially protected. In case of different directions of the social responsibility we decided to examine what kind of social responsibility is implementing by business representatives, in order to obtain full information about current situation. The question about the social responsibility of them, the 
most of them (40\%) preferred single aid due to the charity, the next was health insurance (34\%), not only with the participation of the employer, also including the employee, in third place were the businessmen, which assume that, the minimum wage of employee should not be less than the subsistence minimum $(12 \%)$, however they named the reasons ,that they are not able to implement the payroll changes in this direction, and $14 \%$ considers, that they have no commitment about the social responsibility.

Figure 1: The social responsibility measures of business representative

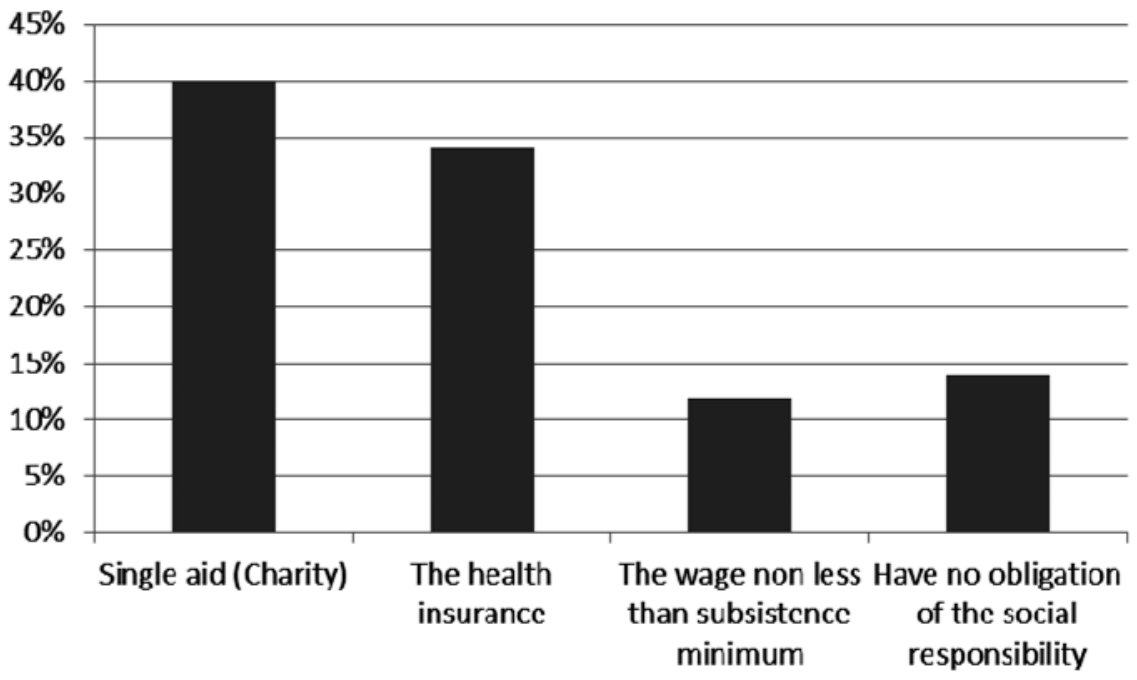

As we can see, the business has not yet comprehended the role of human capital to make their activity successful. Because the business sector in Georgia is still weak, they have to work under serious risk factors and uncertainty. Therefore, the expectation of social responsibility of business from powerful companies working in rich and stable economy is fair, but it is unfair to impose the same requirement for the private sector in developing country like Georgia. The additional demand of the social responsibility of business may be reduce the viability and competitiveness of Georgian companies. The studies about research of private polls and abovementioned organizations showed, that in Georgia the social responsibility of business for the society somewhat is known. The large part of businessmen properly estimates good corporative importance of citizenship, but the social responsibility mainly represented by the charity and do not intersect main priorities, which connected with the creation of jobs. Zarecki A.D formulates internal and external social responsibility and considers that internal social responsibility is at first the event of relationship with the personnel:

- The safety

- Payment of stable wages 
- The medical and social insurance of employees;

- To improve the qualification of the staff due to training program;

- To help in critical situations;

- The external social responsibility includes:

- The Sponsorship and the charity;

- To participate in ecological programs of the state, region and municipality;

- The society relations in crisis situation;

- To output of the quality products. (Zarecki, 2013, p. 92)

Furthermore, the measures of social responsibility can be grouped by mandatory and responsibility forms. The mandatory forms are: the payment of taxes, the implementation of legislation, the social protection of employees, fulfilling the consumer's expectations, to care for ecological safety. The responsibility forms are: the charity, the funding for education.

All measures directly or indirectly directed to improvement of social condition of the population, and healthy society is the key to success of business. To prove this we use the opinion of the founder of corporation "Hewlett Packard "David Packard: "many consider that the goal of any company's existence is to earn money. Despite the fact, that the money is important result of activity, we came to the conclusion: the company is the group of people, collectively solve the problem which unable to solve separate persons- contributing the society life". Such attitudes towards the corporative social responsibility in each country was proceeded the development of the charity, which was discussed by two aspects: at first, when rich person from his incomes was assisting the recipient, and second, when the commercial organizations transfer incomes to charity funds. In first case, we are dealing with purely altruistic actions, and second is corporative charity. The goals of any commercial organizations are to gain profit, which is the result of economical effectiveness of activity. So in the charity implemented by commercial organizations must be at some doses profit-making motive, otherwise the connection between charitable activity and commercial organizations can be interrupted.

\section{Conclusion}

Corporative responsibility in Georgia is in embryonic stage. Nowadays operates 57 charitable funds, but social problems are still the high quality, one reason for this is, that 1650000 socially vulnerable person standing face to face not very large - scale of business activity. Here is one of the principles: "the expense of business increases, the condition of vulnerable people doesn't improve" so charitable activity despite the tax benefits: after deduction from 
gross income to deduct of $10 \%$ of remaining amount, still cannot become corporative charity. The reason must be sought in socio-economic conditions of the country. Namely, due to the low level of life the business could not received the reverse effect from charitable activity, which can received the business structures of developed countries. In order to alleviate the problem we consider it necessary the joint participation of the business, the state and the society for improvement of social condition. In this direction the government should limit social assistance for the people, which are capable to working and in return to offer employment opportunities, and should facilitate the business structures, besides the society should understand the reduction of social assistance and to pay the main attention for increasing the formation and the use of finances of charitable funds, transparency of spending control, because the corporative social responsibility increases the traditional understanding of business responsibility. This is not only economical institute, its activity goes beyond boundaries of specific companies and impacts on society members, the state, and is involved in resolving of social issues.

\section{Literature}

- $\quad$ Bashka, N.V. and Danyluk, A.A. (2003). Corporate Social Responsibility. Tutorial publishing of Tyumen State University.

- COM (2001). Promoting a European Framework for Corporate Social Responsibility, (366).

- Friedman, M. (2006). "Capitalism and Freedom" translation from English. New publishing M.

- Khoperia, L. (2011). The role of corporative social responsibility and public sector. The center of strategic research and development of Georgia. The bulletin \#120.

- Roik, V.D. (2000). Social protection: the meaning of sense. The Person and work, (11).

- Smirnov, V.T. and Soshnikov, I.V. (2005). Vlasov Human Capital Management. Textbook.

- Zaretsky, A.D. (2011). Ivanova ie Corporate Social: World and national practice. The success of modern science, (12), 91-93. 
Prof. dr Asie Tsintsadze,

Fakultet za ekonomiju i poslovanje,

„Šota Rustaveli“ državni univerzitet u Batumiju, Gruzija

Doc. dr Lilit Meloyan-Phutkaradze,

Fakultet za ekonomiju i poslovanje,

„Šota Rustaveli“ državni univerzitet u Batumiju, Gruzija

\section{PRIVREĐIVANJE KAO DEO MEHANIZMA DRUŠTVENE ZAŠTITE STANOVNIŠTVA}

\section{S a ž e t a k}

Društvena zaštita stanovništva je jedan od glavnih pravaca u naporima svake vlade. U modernim vremenima društvena zaštita se odvija zahvaljujući socijalnoj politici, a sprovođenje ove politike se vrši od strane vlade. Trenutno, u Jermeniji, glavni mehanizam društvene zaštite je socijalno osiguranje, koje se sprovodi od strane Ministarstva rada, zdravlja i socijalne politike. U Jermeniji, agencija za društvene subvencije je zadužena za zdravstvenu zaštitu i medicinske programe. U uslovima tržišne privrede, gde je uticaj države ograničen, došlo je i do smanjenja sredstava društvene zaštite. U modernim uslovima mehanizmi društvene zaštite bi trebalo da se razvijaju saradnjom države i privatnog sektora. Postaje neophodno da se poveća učešće privrede u društvenoj zaštiti stanovništva, koja bi sa više dobrotvornih davanja bila i društveno odgovornija. Najvažniji cilj svake vlade je efikasno zapošljavanje stanovništva. Cilj istraživanja je da se ispita uloga privrednika u društvenoj zaštiti; da se definišu problemi i ponude konkretne mere za njihovo rešavanje. Jasno je da se sprovođenje društvene zaštite može u potpunosti staviti na teret privrednika, kao što privreda može osigurati efikasno funkcionisanje zapošljavanja i na taj način doprineti razvoju njihovih preduzeća i socijalnoj politici države.

Ovaj rad formuliše predloge u smislu saradnje privrede i države i njihovih aktivnosti ka efikasnoj društvenoj zaštiti stanovništva.

Ključne reči: socijalno osiguranje, politika društvene zaštite, društvena zaštita 